\title{
Synthetic Studies on Tedanolide: Stereoselective Synthesis of the C13-C21 Fragment
}

\author{
Su Ho Park, Jae Ki Min, Se Hwan Park, and Hyo Won Lee \\ Department of Chemistry, Chungbuk National Lniversitw, Cheongiu, Chungbuk 361-763, Korea \\ E-mail: hwleéachungbukack ${ }^{\prime}$ \\ Received December 31, 2008, Accepted Jantury 31, 2009
}

Key Words: Macrolide, Tedanolide. Antitumor compounds, Metal-mediated allylation

The highly cytotoxic macrolide tedanolide (1) was isolated by Schmitz and co-workers from the Caribbean sponge Tedanis ignis in 1984. This antitumor macrolide features four labile aldol units. a side chain containing a hydroxy epoxide ring, an 18-membered lactone. and the crowded contiguous chiral centers at C $16-\mathrm{C} 19$. It also shows in vitro cy totoxicity against $\mathrm{KB}$ and $\mathrm{PS}$ cell lines (ED $\mathrm{ED}_{50}{ }^{\circ}$ : $250 \mathrm{pg} / \mathrm{mL}$ and 16 $\mathrm{pg} / \mathrm{mL}$, respectively) and in wivo antitumor activity. increasing the lifespan of mice implanted with lymphocytic leukemia cells $(23 \%$ at $1.56 \mu \mathrm{g} / \mathrm{kg})$. Because of their unusual strnctural features and powerful biological activities. 1 and 2 have attracted considerable attention of synthetic chemists. Recently Kalesse ${ }^{2 .+b}$ and Smith ${ }^{2+}$ have reported successful total sy nthesis of tedanolide (1). respectively. We have reported our synthetic

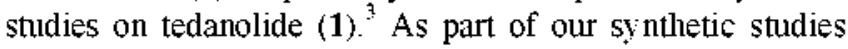
toward 1, we now report a concise and stereoselective synthesis of the C13-C21 fragment 3 .

Our retrosynthetic analysis of tedanolide (1) is outlined in Scheme 1. Disconnections at the lactonic $\mathrm{C}-\mathrm{O}$ bond and a bond between $\mathrm{Cl} 2$ and $\mathrm{Cl} 3$ produce subunits of aldehỵde 3 and ketone 4 . The $\mathrm{C} 13-\mathrm{C} 21$ aldehyde 3 can be prepared by the Roush asymmetric crotylation from aldehyde 5 . Our present synthesis focuses on the preparation of $\mathbf{5}$. For the key stereoselective $\mathrm{C}-\mathrm{C}$ bond formation of 5 , we relied on a

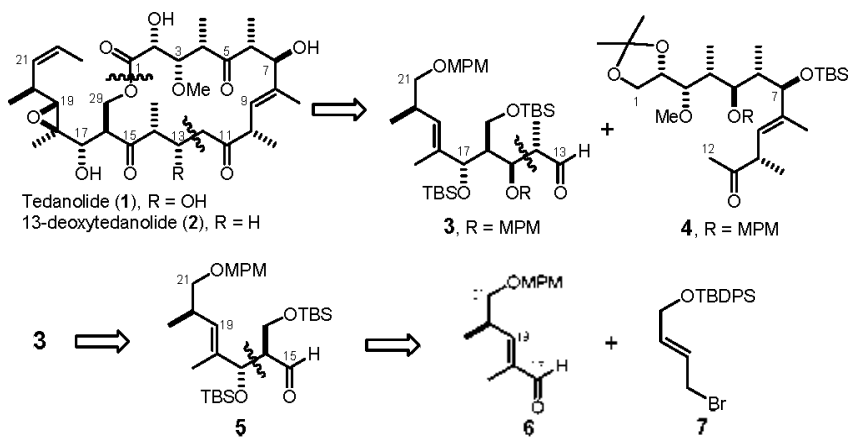

Scheme 1. Retrosinthetic analy sis

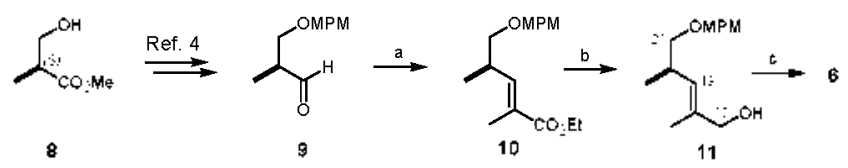

Scheme 2. a) $\mathrm{Pl}_{3} \mathrm{PCCH}_{3} \mathrm{CO}_{2} \mathrm{Et}, \mathrm{CH}_{\hat{*}} \mathrm{Cl} l_{\hat{-}}$, rt, $24 l_{1}, 85 \%$ b) DIBAL-H, THF, $\left.-78^{\circ} \mathrm{C}, 1 \mathrm{lh}, 96 \%, \mathrm{c}\right)(\mathrm{COCl}), \mathrm{DMSO}, \mathrm{Et}_{3} \mathrm{~N}, \mathrm{CH}_{2} \mathrm{Cl}_{2},-78^{\circ} \mathrm{C}$ to 0 ${ }^{\circ} \mathrm{C}, \mathrm{Ih}, 92 \%$. metal-mediated allỵlation reaction between aldehyde 6 and allylic bromide 7 with the control of $\mathrm{C} 16-\mathrm{Cl} 7$ stereogenic centers. The aldehyde 6 was synthesized from (S)-methyl 3-hydroxy-2-methylpropionate as reported in the literature.

Our synthesis commenced with the preparation of aldehyde 6. For the synthesis of aldehyde 6 (Scheme 2), aldelyde 9. readily available from (S)-methyl 3-hydroxy-2-methylpropionate (8) in three steps. was subjected to the Wittig reaction to furnish $\alpha . \beta$-unsaturated ester $10(E Z Z=95: 5)$. And then 10 was reduced regioselectively with $\mathrm{DIBAL}-\mathrm{H}$ to give allylic alcohol 11 in good yield. The Swern oxidation of 11 completed the șyntheșis of the desired aldehỵde 6 in $75 \%$ overall yield from 9 in three steps.

With aldehyde 6 in hand, we carried out metal-catalyzed allỵlation reaction. ${ }^{6}$ Several kinds of metals have been employed as mediators for the allylations of aldehyde 6 with allylic bromide 7 (Scheme 3). Among these. indium and zinc are widely utilized. The use of indium metal as a mediator under the Barbier-type conditions was first reported in $1988^{\text {to }}$ Compared to other metals. indium offers a number of advantages, including its low toxicity. tolerance toward air and moisture and due to its low ionization potential, a high reactivity in the absence of external activators and proton sources. Zinc was also employed in the Barbier-type allylations and it has been likewise proved to be a lighly useful mediator for the allylation of various substrates. ${ }^{6 t}$ In contrast to indium-mediated allylations, which are commonly carried out in THF/water nixtures without additives. the use of zinc generally requires the presence of saturated aqueous $\mathrm{NH}_{4} \mathrm{Cl}$ as a proton source together with the organic solvent.

Indium or zinc mediated coupling of aldehỵde 6 and allỵlic

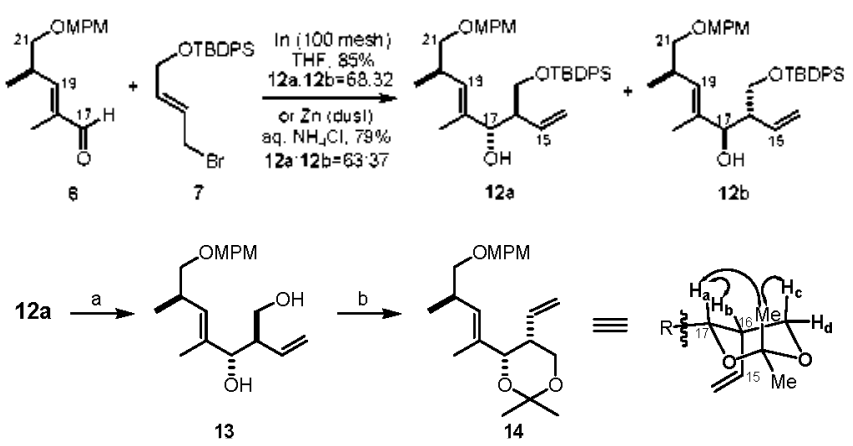

Scheme 3. a) TBAF, THF, rt, 1h, 96\%: b) $\mathrm{Me}_{2} \mathrm{C}(\mathrm{OMe})_{2}$. PPTS, $\mathrm{CH}_{2} \mathrm{Cl}_{2}, 0^{\circ} \mathrm{C}, 2 \mathrm{~h}, 95 \%$ 
<smiles>[M]OC[C@@H](C=C)[C@@H]([18OH])/C(C)=C/C(C)CO[Na]</smiles>

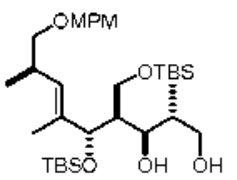

18<smiles>C=CC(CO[13CH3])[C@@H](C=C(C)C)C(C)=CC(C)C</smiles>

15

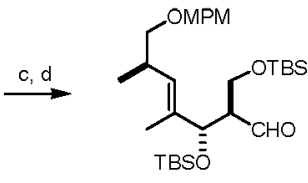

5

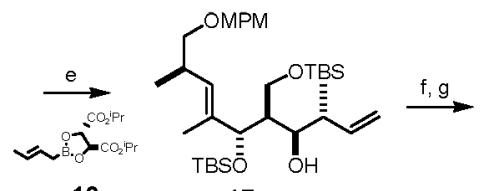

16

17

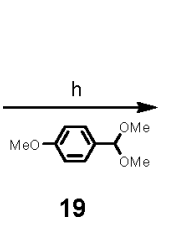

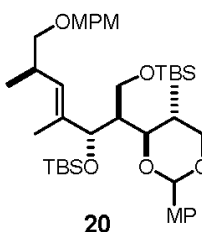

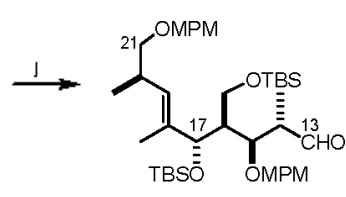

Scheme 4. a) TBAF, THF, it, lh, 96\%; b) TBSOTf, 2,6-lutidine, $\mathrm{CH}_{2} \mathrm{Cl}_{2}, 0{ }^{\circ} \mathrm{C}, 2 \mathrm{~h}, 80 \%$, c) 0sO, NMO, acetone, rt , 3h, 75\%: d) NaIO, $\mathrm{THF}: \mathrm{H}_{2} \mathrm{O}=4: 1$, th, $1 \mathrm{~h} ;$ e) $16,4 \mathrm{~A} \mathrm{MS}$, toluene, $\left.-78{ }^{\circ} \mathrm{C}, 3 \mathrm{~h}, 90 \%: \mathrm{f}\right) \mathrm{O} \mathrm{O}_{4}, \mathrm{NMO}$, acetone, rt, $4 \mathrm{~h}, 88 \%$ : g) NaIO, THF: $\mathrm{H}_{2} \mathrm{O}=4: 1$, rt, $3 \mathrm{~h} ; \mathrm{NaBH}$, $0^{\circ} \mathrm{C}, 1 \mathrm{~h}, 87 \%$; h) $19, \mathrm{CSA}_{2} \mathrm{CH}_{2} \mathrm{Cl}_{2}, 0^{\circ} \mathrm{C}, 3 \mathrm{~h}, 83 \%$, i) DIBAL-H, THF, $\left.-78^{\circ} \mathrm{C}, 1 \mathrm{~h}, 71 \%, \mathrm{j}\right) \mathrm{DMP}, \mathrm{NaHCO}_{3}, \mathrm{CH}_{2} \mathrm{Cl}_{2}, 0^{\circ} \mathrm{C}, 1 \mathrm{~h}, 85 \%$.

bromide 7 produced a $\sim$ : 1 mixture of diastereomeric alcohols at $\mathrm{Cl7}$ (Scheme 3). Although no excellent selectivity was observed the two diastereomers could be easily separated by flash column chromatography. In order to determine the relative stereochemistry of the major product $12 \mathrm{a}$ the removal of a TBDPS silyl group of 12a with TBAF furnished the diol 13. The 1,3-diol 13 was then converted into acetonide 14 . The configurations at $\mathrm{Cl} 6$ and $\mathrm{Cl} 7$ were confirmed by the Mosher's method and NOE analysis of acetonide 14 . respectively.

The next step along the sequence was the introduction of a $\mathrm{C} 13-\mathrm{Cl} 15$ homoally lic alcohol unit using the Roush asymmetric crotylation $^{8}$ (Scheme 4). Deprotection of TBDPS silyl ether 12a with TBAF furnished the intermediate 1.3-diol. The next step was the protection of two hydroxy groups as TBS silyl ethers. The treatment of the intermediate diol with TBSOTf in the presence of 2,6-lutidine provided compound 15 . The terminal vinyl group in 15 was converted into the corresponding aldehyde 5 by initial osmium-mediated dihydrosylation followed by oxidative cleavage with $\mathrm{NaIO}_{4}$. The subsequent Roush asy mmetric allylation reaction upon aldehy'de 5 gave predominantly the desired homoallylic alcohol $17(95: 5 \mathrm{dr}$ by ${ }^{1} \mathrm{H} N M R$ analy sis) with the requisite stereochemistry at $\mathrm{Cl} 4$ and $\mathrm{C} 15$ of tedanolide (1) as we expected. Homoallylic alcohol 17 was treated with $\mathrm{O}_{5} \mathrm{O}_{4}-\mathrm{NaIO}_{4}$ followed by reduction to afford the diol $18 \mathrm{in}$ high yield. The 1.3 -diol 18 was protected as 4-methoxybenzylidene (MPM) acetal 20, which was then reduced regioselectively with DIBAL- $\mathrm{H}$ in $\mathrm{CH}_{2} \mathrm{Cl}_{2}$ to give primary alcohol 21 in good yield. Finally the Dess-Martin oxidation $^{9}$ of 21 completed the synthesis of the desired aldehy'de 3 .

In conclusion, the C13-C21 segment 3 of tedanolide (1) was obtained in $20 \%$ yield over 14 steps from the aldelyde 9 . The key steps were metal-mediated allylation and the Roush astmmetric crotylation. Ongoing efforts toward the completion of tedanolide (1) are currently in progress and will be reported in due course.

Aclonowledgments. The financial support from the Korea Science and Engineering Foundation (Grant-in-aid: R012005-000-10032-(0) was greatly appreciated.

\section{References}

I. Schmitz, F. J.; Gunasehera, S. P; Yalamanchili, G.; Hossain, M. B.; Var der Helm, D. J. Ant. Chem. Soc. 1984, 106, 7251-7252.

2. (a) Elrrlich, G.: Hassfeld, I.; Eggert, U.; Kalesse, M. J. Am. Chem. Soc. 2006, 128, 14038-14039. (b) Ehrlich, G.; Hassfeld, T.; Eggert, U; Kalesse, M. Chem. Eur. J. 2008, 14, 2232-2247. (c) Smith, A. B.; Lee, D. J. Ant. Chem. Soc. 2007, 129, 10957-10962.

3. Park, S. H.; Lee, H. W. Bull. Korew Chem. Soc. 2008, 29, 1447-1448.

4. Walkup, R. D;; Kane, R. R.; Boatman, P. D., Jr.; Cunningham, R. T. Tetwhedron Lett. $1990,52,7587-7590$.

5. Mancuso, A. T. Swem1, D. Sinthesis 1981, 165-185.

6. (a) Araki, S.; Ito, H, Butsugan, Y. J. Org. Chem. 1988, 53, 1831-1833. (b) Killinger, T. A.: Boughton, N. A.: Runge, T. A:; Wolinsky, T. J. Organomet. Chem 1977, 124, 131-134. (c) Park, S. H.: Yoon, H. K.: Lee, H. W. Bull Komean Chem. Soc. 2006, 27 , 1519-1520. (d) Lee, P. H. Bull. Korew Chem. Soc. 2007, 28, $17-28$

7. Dale, T. A.; Mosher, H. S. J. Am Chem. Soc. 1973, 95, $512-519$.

8. Roush, W. R.; Adem, M. A.: Walts, A. E.: Harris, D. J. J. Am. Chem. Soc. 1986, 108, 3422-3434.

9. Dess, D. B. Martin, T. C. J. Org. Chent. 1983, 48, 4155-4156. 